\title{
Biograficzne trajektorie sylwetek uczonych jako perspektywa ujmowania ludzkich uwarunkowań tego, co specyficznie ludzkie
}

[Uczeni z odległej i nieodległej przeszłości. Rekonstrukcje. Interpretacje. Refleksje. (2019). Żywczok A., Kitlińska-Król M. (red.). Katowice: Wydawnictwo Uniwersytetu Śląskiego, 199 s.].

Książka jest pracą wieloautorską o mocno zaznaczonej merytorycznej tożsamości przedmiotowego pola zainteresowania. Biorąc pod uwagę przyjęte kryteria, zgromadzony materiał jest treściowo monotematyczny oraz powiązany wspólnymi ramami założeń epistemologicznych i metodologicznych. Treści pracy są starannie zredagowane w warstwie narracji językowej, dobrze ustrukturyzowane oraz metodycznie znormalizowane. Książka jest wyrazem wartościowego interdyscyplinarnego przedsięwzięcia studialnego o walorach naukoznawczych i historiograficznych.

Autorom poszczególnych rozdziałów towarzyszy metodyczna świadomość, wyrażająca się w sygnalizowaniu, uwyraźnianiu lub eksponowaniu trzech zasadniczych aspektów poznawczych w konstrukcji opracowanych przez siebie wypowiedzi, które można określić mianem: 1) ujmowania wydarzeń i faktów biograficznych ludzi nauki jako przesłanki w odczytywaniu i naświetlaniu ich aktywności i osiągnięć naukowych; 2) ujmowania aktywności i działalności naukowej jako przesłanki w odczytywaniu preferowanych przekonań, ujęć i modeli nauki jako wyodrębnionego obszaru działalności ludzkiej; 3) ujmowania formułowanych bezpośrednio lub pośrednio modeli uprawiania nauki oraz indywidualnego etosu pracy naukowej jako przesłanki w odczytywaniu i nadawaniu społeczno-kulturowych znaczeń aktywności i działalności przywoływanych naukowców.

Tak uwyraźniana intencja badawcza, ujmująca intelektualne osiągnięcia w kontekście biograficznych trajektorii losu historycznych podmiotów (myślicieli, filozofów, twórców, naukowców), ma różne swoje reprezentacje w literaturze przedmiotu. Do dziś jednym z przykładów realizacji tak ujmowanej intencji badawczej jest dzieło o wyjątkowej wartości historycznej - zapis życia i dzieła starożytnych filozofów greckich - życia, które wyraża filozoficzne dzieło i dzieła, które jest samoobiektywizacją filozoficznego życia (Diogenes Laertios 1988, s. 6). Tak artykułowana intencja 
badawcza pozwala również ujmować sensu stricto humanistyczne zainteresowania przez pryzmat tego, co stanowi sedno humanistyki, a zatem samego problemu człowieka, jego kulturotwórczego potencjału i sprawczości - „sylwetki naukowej” i „osobowości intelektualnej”, wyrażających swoisty egzystencjalny modus i sposób bycia (Wojnar 2000, s. 241). „Drogi myślowego dążenia” człowieka zawsze bowiem w pełni ukazują się na biograficznej „linii życia”, pośród specyficznego „układu życiowych możliwości” i „wichru dziejowego”. To na tak ujmowanej „linii życia”, znaczonej zawiłościami „długodystansowej podróży” oraz „śladów” chronicznego wysiłku, możliwe jest ujęcie ludzkich warunków tego, co specyficznie ludzkie (Kotarbiński 1986, s. 317).

Praca Uczeni z odległej i nieodległej przeszłości. Rekonstrukcje. Interpretacje. Refleksje składa się z wstępu, dziesięci autorskich rozdziałów, zakończenia oraz streszczenia w języku angielskim. Wstęp stanowi rzeczowe wprowadzenie do celów, założeń i treści książki. Zakończenie zawiera zaś podsumowanie zasadniczych intencji redaktorów książki, którzy jednocześnie umieścili profil prezentowanych studiów w kontekście szerszych tendencji współczesnych nauk humanistycznych i społecznych oraz zjawisk współczesnego świata. Rozdział pierwszy ukazuje zarówno sylwetki uczonych z starożytnej Italii, jak i specyficzne uwarunkowania tego świata w działalności wspomnianych osób. Z kolei rozdział drugi przenosi nas w świat średniowiecznej Europy, dla której klasztory były centrami gromadzącymi zasoby wiedzy naukowej oraz kształcącymi elity społeczne, czyli osoby pochodzące z wyższych sfer. Rozdziały od trzeciego do dziewiątego, w kolejności poświęcone są natomiast takim sylwetkom ludzi nauki, jak: Jan Niecisław Baudouin de Courtenay, František Drtina, Tadeusz Zieliński, Kurt Alder, Jean Piaget, Tadeusz Kotarbiński, Otton Lipkowski. Opracowania te w różnym stopniu koncentrują się wokół wskazanych w niniejszej recenzji zasadniczych aspektów poznawczych oraz zagadnień składających się na kwestie, które w dalszej części recenzji określam poprzez odwołanie się do formuły zasadniczych warstw przekroju analitycznego. W końcu, rozdział dziesiąty poświęcony jest sylwetkom zapomnianych nauczycieli - intelektualistów i społeczników, związanych z Górnym Śląskiem po zakończeniu II wojny światowej, tj.: Waleriana Bętkowskiego, Michała Jaworskiego, Leopolda Kobierskiego, Stefanii Mazurek, Jana Smolenia, Urszuli Szumskije, Władysława Ślęzak, Czesława Thullie, Antoniego Witkowskiego. Postaci te ukazane są w kontekście trudnych powojennych czasów, skutkujących specyficznymi uwarunkowaniami oraz ograniczeniami ich działalności i twórczości naukowej.

Ujmując rzecz ogólnie i całościowo, w sposób umowny można wskazać na zasadnicze warstwy przekroju analitycznego, w obrębie których rozstrzygają się wartości dodane niniejszej książki. Składają się one na przedmiotowo wyrazistą, tworzącą specyficzny obszar poznawczego zainteresowania narrację treści książki, z której wyłaniają się trzy specyficzne i komplementarne względem siebie obrazy/ reprezentacje poznawczej eksploracji, w większości wprost uwidocznione w każdym z rozdziałów składających się na treści książki: 
1. Warstwa eksploracji indywidualnych uwarunkowań biograficznych - obrazy/ reprezentacje poznawczej eksploracji sylwetek naukowców. W ramach tej warstwy narracyjnej treści książki mamy do czynienia z prezentacją sylwetek wybitnych uczonych - znanych, choć może przede wszystkim - zapomnianych lub nieznanych. Owe obrazy ukazane są przez pryzmat zarówno szerokich pól działalności twórczej, społecznej i kulturowej, jak i w wielu przypadkach znamienitych i na skalę światową rozpoznawalnych osiągnięć w poszczególnych wyspecjalizowanych obszarach nauki. Mówimy tu zatem o warstwie rekonstrukcji i prezentacji wydarzeń biograficznych, które składają się na sylwetkę/obraz danego naukowca. W ten sposób tworzona jest swoista mapa indywidualnych cech i predyspozycji, deklarowanych lub preferowanych wartości, nastawień i odniesień względem otaczającego świata, systemu motywacji i stylu pracy oraz ideałów i celów, rozpatrywanych zarówno w kategoriach zawodowych (pracy naukowej), jak i życiowych (ogólnoludzkich, egzystencjalnych). Bez wątpienia tak sprofilowana biograficzna wiedza pozwala uwidaczniać różne indywidualne uwarunkowania, fakty i wydarzenia, które przygotowywały grunt pod przyszłą działalność i osiągnięcia naukowe przywoływanych ludzi nauki, jak również składały się na tę działalność i osiągnięcia lub też przesądzały o kolejach/losach środowiskowej, społecznej czy pokoleniowej recepcji ich działalności i twórczości.

W ten sposób spotykamy się z sylwetkami uczonych, którzy na trajektorii swego biograficznego losu doświadczają uznania, docenienia i afirmacji (np. poprzez nominację do nagrody Nobla lub jej uzyskanie) lub też odrzucenia, zapomnienia i marginalizacji (np. poprzez doświadczanie ostracyzmu i różnych form nieprzychylności). Ludzkie życie to biografia. Koleje życia człowieka jako jednostki określają zaś możliwości i niemożliwości jego sposobów bycia w świecie, działalności i twórczości. Bieg życia ludzi nauki uwidacznia zaś ten szczególny wymiar obecności celów, zadań, działań i wysiłków skoncentrowanych na aktywnościach, poprzez które nauka jest reprezentowana. W tym znaczeniu biograficzne koleje życia ludzi nauki nabierają szczególnego znaczenia jako istotny obszar zachodzenia określonych, jednostkowo reprezentowanych prawidłowości, mechanizmów i procesów. Ich znajomość może stanowić cenne źródło wiedzy i naukowej eksploracji podczas próby ustalania pośrednich lub bezpośrednich prawidłowości, mechanizmów i procesów, decydujących o kolejach samej nauki, jej sukcesach i klęskach, utrwalanym lub podupadającym etosie pracy naukowej, perspektywach rozwoju na przyszłość lub też braku takich perspektyw.

2. Warstwa eksploracji uwarunkowań historyczno-społecznych jako kontekstów życia i twórczości ludzi nauki - obrazy/reprezentacje poznawczej eksploracji świata życia codziennego naukowców. W tym przypadku uwidaczniane są (rekonstruowane, przybliżane, uwyraźniane) konteksty egzystencjalne (historyczne, kulturowe, społeczne, pokoleniowe, sytuacyjne) jako istotne przesłanki w ukazaniu determinant, złożoności i trudności, a czasami wręcz tragizmu trajektorii losów sylwetek uczonych i ich osiągnięć jako synów własnych czasów oraz specyficznego 
środowiska życia. Historia rozwoju nauki w jej różnych aspektach (eksploracyjnych lub aplikacyjnych) jako zobiektywizowanego wytworu społeczno-kulturowego ukazana zostaje więc jako historia konkretnych ludzi w specyficznych kontekstach życia, towarzyszących mu uwarunkowań oraz wynikających z nich twórczych możliwości lub blokujących limitów. W tej warstwie można dostrzec moc życiowych okoliczności, które tworzą dogodne warunki do rozwoju danej działalności i twórczości lub też działalność i twórczość tę utrudniają, redukują lub w ogóle uniemożliwiają. W ten sposób trajektoria losów poszczególnych ludzi może być wykuwana przez moc odmiennych warunków życia społeczno-kulturowego oraz towarzyszących im determinant. Synowie tych samych czasów, noszący w sobie tej samej miary potencjał i w podobny sposób przygotowani do pracy naukowej, podążają innymi drogami. Odnajdujemy ich w zupełnie różnych miejscach kariery naukowej, ponieważ ich własny specyficzny świat - życia codziennego, ustrukturyzowanych warunków społecznych, milczących lub wypowiadanych wprost kodów i rytuałów kulturowych - ustanawia istotną egzystencjalnie różnicę warunków życia. Może ona stać u podstaw różnic w wykorzystaniu przez nich owego potencjału, przebiegu kariery naukowej czy możliwościach ich rozwoju.

Poznanie oraz opis działalności i twórczości ludzi nauki, wraz z uwzględnieniem specyficznych realiów historyczno-kulturowo-społeczno-środowiskowo-pokoleniowych, pozwala więc zrozumieć określone wybory, strategie lub zasadność doboru środków, przy pomocy których realizowane były dane przedsięwzięcia naukowe. Znajomość realiów i uwarunkowań, w ramach których rozgrywała się określona działalność i twórczość ludzi nauki, pozwala też odkryć i nadać biegowi ludzkiego życia oraz ludzkim czynom znaczenia i rangi. Gdyby to wszystko pominąć osiągnięcia ludzkie mogłyby stać się niewidoczne lub nieczytelne. W taki właśnie sposób inne znaczenie i ranga towarzyszyć będzie np. konspiracyjnej działalności naukowca, który w czasach okupacji nauczał na tajnych kompletach, kształcąc studentów, a inna ranga i inne znaczenie będzie miała analogiczna działalność dydaktyczna, realizowana w czasach pokoju i w ramach instytucjonalnego stosunku pracy, zabezpieczanego pakietem praw obywatelskich i pracowniczych.

3. Warstwa eksploracji sposobów rozumienia nauki jako specyficznej aktywności i działalności ludzkiej, jej funkcji, zadań, celów oraz samej misji/powołania uczonych - obrazy/reprezentacje poznawczej eksploracji nauki i uczonych w całokształcie symbolicznych i materialnych form życia społeczno-kulturowego. W ramach tej warstwy narracyjnej treści książki uwidocznione zostają różne modele myślenia o tym, czym jest, czym może być lub czym powinna być nauka oraz same przeświadczenia/przekonania o tym, kim są, kim mogą być lub kim powinni być uczeni, biorąc pod uwagę ich specyficzne miejsce (funkcje, zadania, odpowiedzialność, misje/powołanie), uwyraźniane lub definiowane historycznie i pokoleniowo w obrębie określonych form organizacji życia społecznego i kulturowego. W sposób szczególny uwidaczniają się tu różne dylematy, problemy, konieczności, kontrowersje lub zagrożenia, z którymi nauka i uczeni wciąż na nowo 
i na miarę własnego czasu i miejsca są konfrontowani, w różnych specyficznych historyczno-kulturowo-społeczno-środowiskowych odsłonach, poprzez różne konieczności i wyzwania. Analiza tych zagadnień, wyartykułowana w mniejszym lub większym stopniu w poszczególnych rozdziałach, ukazuje, że uczeni, nauka, strategie oświatowe i „polityka oświatowa” mają swoje permanentnie powracające, choć w zupełnie nowych odsłonach historycznych, społecznych czy kulturowych, problematy. W każdym pokoleniu, i ze względu na zmienną strukturę uwarunkowań i wyzwań życiowych, uczeni postawieni są przed koniecznością ponownego przemyślenia, reorganizacji, rewizji lub dostosowania określonych obszarów społeczno-kulturowej praxis. Jest to sytuacja, w której poszczególni naukowcy odgrywają rolę prowodyrów i kreatorów kierunków określonych zmian i dostosowań lub też rolę petentów i adresatów, których te zmiany i dostosowania dotykają, wpływając na stabilizację ich własnej pracy naukowej lub ich własne perspektywy zawodowe, związane z możliwością prowadzenia działalności naukowej.

Z tego względu ta warstwa treściowa książki, ujmowana w przekroju analitycznym, może stanowić przyczynek do namysłu i dyskusji nad aktualnymi bolączkami i kontrowersjami, z którymi zmaga się polski system szkolnictwa wyższego oraz w ogóle polska nauka. W różnych dylematach i postulowanych rozwiązaniach, z którymi stykamy się przy okazji prezentacji poszczególnych sylwetek ludzi nauki, ich działalności i twórczości, można bowiem dostrzec analogię do dylematów, problemów i kontrowersji, z którymi mają do czynienia naukowcy doby obecnej. W tym względzie historyczne doświadczenia ludzi nauki, których sylwetki przywoływane są na stronach książki, stanowić mogą nie tylko źródło wiedzy o faktach i wydarzeniach minionych, związanych z życiem naukowców, lecz także mogą stać się inspiracją i podpowiedzią do rozwiązania problemów naszych własnych czasów, poczynienia prób sformułowania i dookreślania pryncypiów i priorytetów świata nauki. Wiedza ta może stanowić również źródło wskazówek dla decydentów i liderów, biorących aktywny udział w aktualnych zmianach i reformach podejmowanych w obrębie szkolnictwa wyższego, choć w tym względzie płonny optymizm zawsze rzucony jest na szalę przeciw nagiemu realizmowi. Rozum władzy rzadko kiedy bowiem podąża tą samą drogą, ma tę samą rangę, racje i uzasadnienia co władza rozumu, choć język komunikacji i dyskursu wydawać się może do złudzenia jednobrzmiący.

Konkludując, można stwierdzić, że praca stanowi interesującą propozycję wieloaurorskiego opracowania, które wpisuje się we współczesne tendencje, zgodnie z którymi w badaniach naukoznawczych i historiograficznych dowartościowana zostaje perspektywa uwarunkowań i struktury świata składającego się na codzienne życie, wraz z jej egzystencjalnym (jednostkowym, subiektywnym, biograficznym) aspektem doświadczenia, jako przesłanki wyjaśniania i rozumienia zobiektywizowanych zjawisk, procesów i wytworów. To one bowiem w ostatecznym rozrachunku konstytuują historyczno-kulturowo-społeczno-pokoleniowe obrazy/reprezentacje 
określonego, ujmowanego całościowo lub parcjalnie, uniwersum symbolicznego, jego determinant, struktury, organizacji i etosu.

Zgromadzony materiał jest wartościowym źródłem wiedzy. Zawiera i uwyraźnia też różne asumpty poznawcze, które mogą stać u podstaw dookreślania i wytyczania nowych pól przedmiotowego zainteresowania, wyrażanych w przewodnich intencjach zamysłu redakcyjnego niniejszej książki, tzn. ujmowania spraw świata specyficznie ludzkiego przez pryzmat specyficznie humanistycznego instrumentarium oraz stojących u jego podstaw aksjomatów jako reprezentacji współczesnych tendencji epistemologicznych i metodologicznych, a ujmując rzecz szerzej, wyrażających historyczno-kulturowo-społeczno-pokoleniowe tendencje oraz świadomość współczesnego człowieka.

\section{Bibliografia}

Kotarbiński T. (1986). Myśli o Ludziach i ludzkich sprawach. Wrocław-WarszawaKraków-Gdańsk-Łódź: Zakład Narodowy Imienia Ossolińskich Wydawnictwo Polskiej Akademii Nauk.

Diogenes Laertios (1982). Żywoty i poglądy słynnych filozofów. Krońska I. (tłum.). Warszawa: Państwowe Wydawnictwo Naukowe.

Wojnar I. (200o). Humanistyczne intencje edukacji. Warszawa: Wydawnictwo Akademickie „Żak”. 